\title{
PENGEMBANGAN SOAL MATEMATIKA BERBASIS KEARIFAN LOKAL DAN DAYA TARIK WISATA RIAU PADA TAHAP PRELIMINARY RESEARCH
}

\author{
Zulfah $^{1}$, Sri Ulfa Insani ${ }^{2}$ \\ ${ }^{1,2}$ Universitas Pahlawan Tuanku Tambusai, Jl. Tuanku Tambusai No 23 Bangkinang, Riau \\ Zulfahasni670@gmail.com
}

\begin{abstract}
The purpose of this study was to analyze the need for mathematics problems based on local wisdom and tourist attractions of Riau, the character of students, the curriculum and concepts in grades VII and VIII of SMP. This needs to be done as a basis for implementing mathematical problem development in this context. This preliminary research stage is part of the Plomp model development research which consists of preliminary research, prototyping phase, and assessment phase. The research instruments used were a check list, interview guidelines, and daily notes. The schools used as research subjects are SMPN 35 Pekanbaru, SMPN 3 Koto Kampar Hulu, MTs 6 Kampar and five other schools. Based on the results of the analysis of the needs and available questions, it is concluded that there is a need for math problems in this context, apart from being able to be used as a measuring tool for students' mathematical abilities, it can also give an impression to students, especially forming a good attitude in accordance with the objectives of mathematics subjects. The results of the analysis of the students concluded that students were interested in the contextual math problems, because basically they had also participated in the implementation of local wisdom, and had visited tourist areas in Riau Province. In the VII and VIII grade curriculum, all material can be linked to the intended context. Based on the concept analysis, there is a material composition that needs improvement.
\end{abstract}

Keywords: Mathematical Problem Development, Local Wisdom

\begin{abstract}
Abstrak
Tujuan penelitian ini adalah untuk menganalisis kebutuhan terhadap soal matematika berbasis kearifan lokal dan daya tarik wisata Riau, karakter peserta didik, kurikulum dan konsep di kelas VII dan VIII SMP/MTs. Hal ini perlu dilakukan sebagai dasar dalam pelaksanaan pengembangan soal matematika dengan konteks tersebut. Tahap preliminary research ini merupakan bagian dari penelitian pengembangan model Plomp yang terdiri dari preliminary research, prototyping phase, dan assessment phase. Adapun instrumen penelitian yang digunakan adalah daftar check, pedoman wawancara, dan catatan harian. Sekolah yang dijadikan sebagai subjek penelitian adalah SMPN 35 Pekanbaru, SMPN 3 Koto Kampar Hulu, MTs 6 Kampar dan lima sekolah lainnya. Berdasarkan hasil analisis kebutuhan dan soal yang tersedia disimpulkan perlunya soal matematika dengan konteks tersebut, selain dapat dijadikan sebagai alat ukur kemampuan matematis peserta didik, juga dapat memberikan kesan kepada peserta didik terutama membentuk sikap yang baik sesuai dengan tujuan dari mata pelajaran matematika. Hasil analisis peserta didik diperoleh kesimpulan bahwa peserta didik tertarik dengan soal-soal matematika yang berkonteks tersebut, karena memang pada dasarnya mereka juga pernah ikut dalam pelaksanaan kearifan lokal tersebut, serta pernah mengunjungi daerah wisata yang ada di Provinsi Riau. Pada kurikulum kelas VII dan VIII seluruh materi dapat dikaitkan dengan konteks yang dimaksud. Berdasarkan analisis konsep terdapat susunan materi yang perlu dilakukan perbaikan.
\end{abstract}

Kata kunci: Pengembangan Soal Matematika, Kearifan Lokal, Daya Tarik Wisata

\section{PENDAHULUAN}

Budaya ataupun kearifan lokal sebagai bagian dari budaya Indonesia yang kaya akan keragaman dan kemajemukan pada masa ini sedang dipertanyakan eksistensinya, menyusul banyaknya kekerasan bernuansa SARA diberbagai wilayah. Indonesia yang dikenal bersifat ramah tamah dan menjunjung adat ketimuran sedikit demi sedikit mulai meninggalkan identitasnya (Rakhmawati \& Alifia, 2018). Pentingnya penguatan pendidikan karakter diperlukan seiring dengan melemahnya karakter bangsa Indonesia(Rakhmawati \& Alifia, 2018). Musfah menyatakan berdasarkan hasil penelitian Komisi Perlindungan Anak tentang demoralisasi karakter peserta didik usia remaja sebesar $97 \%$ sudah pernah menonton video porno, 93,7\% sudah pernah berciuman dengan 
lawan jenis, genial simulation, dan oral sex. Sebanyak 62,7\% telah hilang keperawanannya dan 21,2\% telah melakukan aborsi. Selain data tersebut bentuk dan modus kecurangan dalam ujian nasional juga menunjukkan demoralisai karakter peserta didik(Musfah, 2012).

Pentingnya penguatan pendidikan karakter diperlukan seiring dengan melemahnya karakter bangsa Indonesia(Rakhmawati \& Alifia, 2018). Musfah menyatakan berdasarkan hasil penelitian Komisi Perlindungan Anak tentang demoralisasi karakter peserta didik usia remaja sebesar 97\% sudah pernah menonton video porno, 93,7\% sudah pernah berciuman dengan lawan jenis, genial simulation, dan oral sex. Sebanyak $62,7 \%$ telah hilang keperawanannya dan 21,2\% telah melakukan aborsi. Selain data tersebut bentuk dan modus kecurangan dalam ujian nasional juga menunjukkan demoralisai karakter peserta didik(Musfah, 2012).

Berbagai alternative penyelesaian diajukan untuk mencoba memberikan penyelesaian terhadap masalah ini seperti adanya pembuatan peraturan, undang-undang, peningkatan upaya pelaksanaan dan penerapan hukum atau aturan yanag lebih kuat. Alternatif lain yang banyak dikemukakan untuk mengatasi, paling tidak mengurangi, masalah budaya dan karakter bangya yang dibicarakan adalah pendidikan (Parwati \& Ganesha, 2014)(Hariyanto, 2016). Antara pendidikan dan budaya terdapat hubungan yang erat dalam arti keduanya berkenaan dengan suatu hal yang sama yaitu nilainilai(Adelina Yuristia, 2018). Pendidikan adalah suatu proses menaburkan benih-benih budaya dan peradaban manusia yang hidup dan dihidupi oleh nilai-nilai atau visi yang berkembang dalam suatu masyarakat(Tilaar, 2002).

Matematika sebagai salah satu mata pelajaran yang diajarkan di sekolah juga dapat dijadikan sebagai alat untuk memperkenalkan atau mentransmisi kebudayaan. Matematika perlu difungsikan sebagai sarana dakam menumbuhkembangkan kecerdasan, kemampuan, dan keterampilan, guna membentuk kepribadian peserta didik. Matematika sebagai mata pelajaran pokok di sekolah, harus mampu menjawab tantangan di atas. Pembelajaran matematika harus lebih diberdayakan untuk mendukung pengembangan pribadi peserta didik. Pembelajaran matematika diharapkan tidak hanya berorientasi sekedar materi mateamtika secara an sich, melainkan juga perlu dirubah lebih terbuka menyentuh dimensi lebih luas sehingga mampu berkontribusi lebih besar bagi pengembangan pribadi, termasuk perkembangan soft skill peserta didik (Sumaryanta, 2013). Pada mata pelajaran matematika, pendidikan karakter yang diharapkan pada jenjang kelas $7-9$ adalah teliti, kreatif, pantang menyerah, dan rasa ingin tahu menurut Kementerian Pendidikan dan Kebudayaan Nasional (Nasional, 2010). Sesuai dengan standar isi pada permendikbud nomor 64 tahun 2013, salah satu kompetensi pada muatan matematika yaitu memiliki sikap menghargai kegunaan matematika dalam kehidupan yaitu memiliki rasa ingin tahu, perhatian, dan minat dalam mempelajari matematika, serta sikap ulet, dan percaya diri dalam pemecahan masalah, dengan indikator yaitu memiliki rasa ingin tahu yang tinggi, bersikap penuh perhatian dalam belajar matematika, bersikap antusias dalam belajar matematika, bersikap gigik dalam menghadapi permasalahan, dan memiliki rasa penuh percaya diri dalam belajar 
dan menyelesaikan setiap masalah(Kementerian Pendidikan dan Kebudayaan RI, 2014),(Supiyati, Hanum, \& Jailani, 2019)

Namun kenyataannya, dalam praktek pendidikan kita saat ini justru tujuan kognitif inilah yang sangat diutamakan. Tujuan-tujuan yang telah ditetapkan pada pembelajaran matematika yang salah satunya bertujuan untuk menanamkan nilai-nilai karakter belum termuat secara eksplisit dalam pembelajaran matematika(Pratama, Lutfianto, \& Noviartati, 2019). Nilai-nilai yang sudah disebutkan sebelumnya yang terkandung dalam domain afektif seharusnya dapat dinyatakan dalam proses pembelajaran sehari-hari ataupun melalui bahan ajar matematika sehingga dapat menanamkan nilainilai yang diarahkan kepada masalah-masalah sosial, moral, budaya, dan sebagainya(Dewi, 2015).

Berdasarkan hal tersebut maka peneliti bermaksud memberikan solusi dengan mengaitkan proses pembelajaran matematika dengan kebudayaan yang dapat menanamkan nilai-nilai yang dimaksud sebelumnya. Matematika memang perlu dihubungkan dengan kenyataan, berada dekat dengan peserta didik dan relevan dengan kehidupan masyarakat. Menurut Orey matematika yang disajikan dalam berbagai konteks budaya adalah suatu tuntutan(Supiyati et al., 2019). Bagian dari proses pembelajaran yang akan dihubungkan dengan kebudayaan yaitu tahap evaluasi. Salah satu bentuk evaluasi yang sering dilakukan adalah dengan berupa pemberian tes tertulis. Instrumen tes tulis tersebut dapat dalam bentuk soal pilihan ganda, isian, jawaban singkat, benar-salah, menjodohkan, dan uraian. Intstrumen tertulis inilah yang nantinya akan peneliti kembangkan menggunakan konteks kearifan lokal yangmana kearifan lokal tersebut termasuk ke dalam bagian dari budaya. Selain kearifan lokal, konteks yang peneliti gunakan adalah konteks daya tarik wisata. Berdasarkan informasi yang sudah disajikan maka dilakukan studi pendahuluan atau preliminary research untuk dapat dijadikan dasar dalam melaksanakan pengembangan soal matematika berbasis kearifan lokal dan daya tarik wisata Riau yang dimaksud.

\section{METODE}

Tahapan preliminary research merupakan bagian dari tahapan penelitian pengembangan yang diadapasi dari model Plomp. Model plomp terdiri dari tiga tahapan yaitu tahap preliminary research, tahap prototyping, dan tahap penilaian (assessment phase). Analisis pendahuluan dilakukan untuk memperoleh informasi mengenai permasalahan yang terdapat di pembelajaran matematika. Selain itu melalui analisis pendahuluan, peneliti memperoleh gambaran sementara dari produk yang dikembangkan. Pada tahap analisis pendahuluan ini dilaksanakan analisis kebutuhan, analisis peserta didik, analisis kurikulum, analisis konsep, dan analisis soal yang telah ada, serta studi literature (Zulfah, 2017). Adapun ringkasan dari tahap Preliminary Research sebagai berikut.

\section{Tabel 1.}

Ringkasan Kegiatan pada Tahap Preliminary Research

\begin{tabular}{|l|c|l|l|}
\hline $\begin{array}{c}\text { Kegiatan } \\
\text { Penelitian }\end{array}$ & $\begin{array}{c}\text { Fokus Pertanyaan yang ingin } \\
\text { dijawab }\end{array}$ & $\begin{array}{c}\text { Teknik } \\
\text { Pengumpulan Data }\end{array}$ & $\begin{array}{c}\text { Instrumen } \\
\text { Penelitian }\end{array}$ \\
\hline Analisis & $\bullet$ Apakah tujuan pembelajaran & Wawancara Guru & Pedoman \\
\hline
\end{tabular}




\begin{tabular}{|c|c|c|c|}
\hline Kebutuhan & $\begin{array}{l}\text { matematika yang terdapat dalam } \\
\text { kurikulum telah tercapai? } \\
\text { - Bagaimana guru mengukur } \\
\text { ketercapaian tujuan dari kurikulum } \\
\text { tersebut? } \\
\text { - Apakah soal matematika yang } \\
\text { digunakan pada proses evaluasi } \\
\text { dapat mengukur tujuan } \\
\text { pembelajaran matematika yang } \\
\text { telah ditetapkan? } \\
\text { - Apakah diperlukan soal } \\
\text { matematika berbasis kearifan lokal } \\
\text { dan daya tarik wisata Riau sebagai } \\
\text { referensi atau variasi soal yang } \\
\text { digunakan? }\end{array}$ & Studi dokumentasi & $\begin{array}{l}\text { wawancara } \\
\text { Catatan lapangan }\end{array}$ \\
\hline $\begin{array}{l}\text { Analisis Peserta } \\
\text { Didik }\end{array}$ & $\begin{array}{l}\text { Bagaimana karakteristik peserta } \\
\text { didik di Kelas VII dan VIII } \\
\text { SMP/MTs? } \\
\text { - } \quad \text { Apakah peserta didik mengetahui } \\
\text { kearifan lokal Provinsi Riau? } \\
\text { - Apakah peserta didik mengetahui } \\
\text { daya tarik wisata Riau? } \\
\text { - Apakah peserta didik tertarik jika } \\
\text { diberikan informasi dan soal } \\
\text { matematika dengan konteks } \\
\text { kearifan lokal dan daya tarik } \\
\text { wisata Riau? }\end{array}$ & $\begin{array}{l}\text { Wawancara Peserta } \\
\text { didik }\end{array}$ & $\begin{array}{l}\text { Pedoman } \\
\text { wawancara }\end{array}$ \\
\hline $\begin{array}{l}\text { Analisis } \\
\text { Kurikulum }\end{array}$ & $\begin{array}{l}\text { KD manasaja yang dapat } \\
\text { dikaitkan dengan konteks } \\
\text { kearifan lokal dan daya tarik } \\
\text { wisata Riau } \\
\text { - APakah materi tersebut sudah } \\
\text { memadai untuk mencapai tujuan } \\
\text { kuriukulum? Jika belum, adakah } \\
\text { yang perlu ditambahkan? } \\
\text { - Apakah susunan KD tersebut } \\
\text { sudah terurut dengan baik? }\end{array}$ & $\begin{array}{l}\text { Dokumentasi } \\
\text { Studi literature }\end{array}$ & Catatan lapangan \\
\hline Analisis konsep & $\begin{array}{l}\text { - Konsep-konsep esensial apa saja } \\
\text { yang diperlukan untuk } \\
\text { pembelajaran sehingga dapat } \\
\text { membantu untuk mencapai } \\
\text { kompetensi yang diinginkan? } \\
\text { - Bagaimana urutan dari konsep } \\
\text { yang tersaji? } \\
\text { - Apa saja kisi-kisi dari soal yang } \\
\text { akan dikembangkan? }\end{array}$ & $\begin{array}{l}\text { Dokumentasi } \\
\text { Studi literature }\end{array}$ & Catatan lapangan \\
\hline $\begin{array}{l}\text { Analisis Soal } \\
\text { yang tersedia }\end{array}$ & $\begin{array}{l}\text { Bagaimanakah ketersedian soal- } \\
\text { soal matematika untuk mengukur } \\
\text { kemampuan matematis peserta } \\
\text { didik? }\end{array}$ & $\begin{array}{l}\text { Dokumentasi } \\
\text { Studi literature }\end{array}$ & Catatan lapangan \\
\hline Studi literature & $\begin{array}{l}\text { - Teori apa saja ynag melandasi } \\
\text { pengembangan soal? } \\
\text { - } \quad \text { Bagaimana karakteristik soal-soal }\end{array}$ & $\begin{array}{l}\text { Dokumentasi } \\
\text { Studi literature }\end{array}$ & Catatan lapangan \\
\hline
\end{tabular}




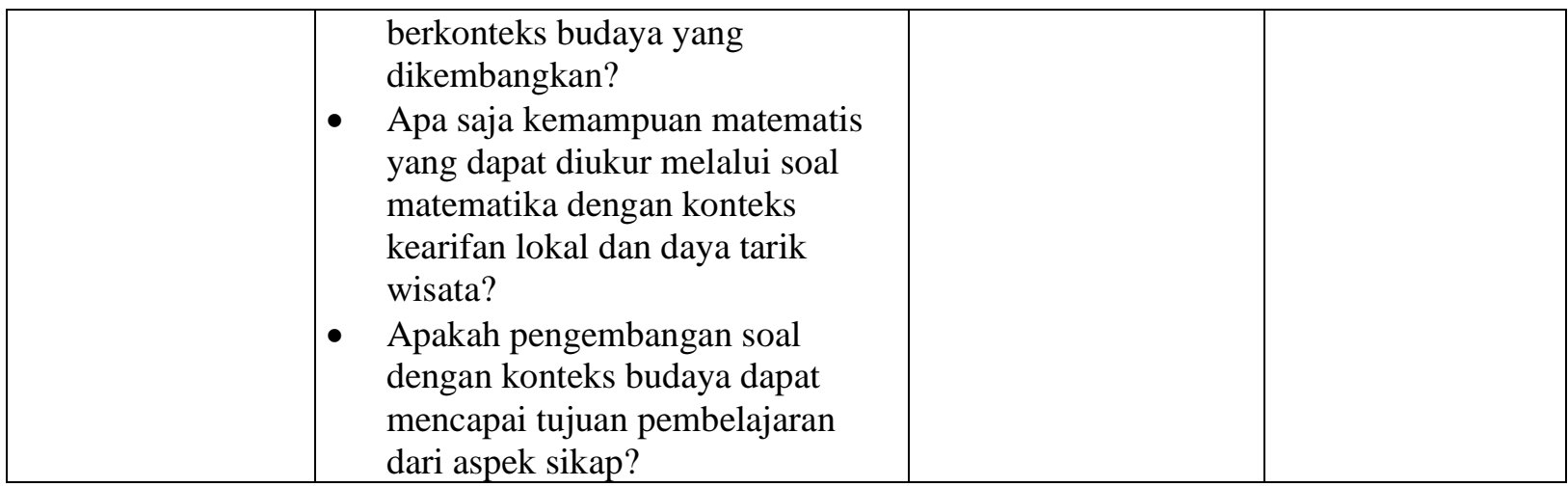

\section{HASIL}

Tahapan pertama dari penelitian pengembangan yang dilakukan adalah Preliminary Research atau studi pendahuluan. Studi pendahuluan pada penelitian ini terdiri dari analisis kebutuhan, analisis karakteristik peserta didik, analisis kurikulum, dan analisis konsep, analisis soal yang telah ada, dan studi literature.

\section{Hasil Analisis Kebutuhan}

Pada tahap analisis kebutuhan dilakukan pengumpulan informasi mengenai permasalahan alat evaluasi yang digunakan oleh para guru mata pelajaran matematika. Peneliti melakukan wawancara dengan 6 orang guru dari SMPN 35 Pekanbaru, SMPN 3 XIII Koto Kampar, SMPN 3 Koto Kampar Hulu, MTSN 6 Kampar, MTs Mu'alimin, SMPN 1 Salo, dan SMPN 2 Bangkinang Kota. Berdasarkan wawancara tersebut diperoleh informasi bahwa selama ini guru memperoleh instrument evaluasi dari buku paket matematika dan buku LKS yang dibeli di sekolah. Soal yang terdapat pada buku tersebut bersifat umum. Soal-soal yang tersedia adalah soal bersifat permasalahan rutin. Memang ada beberapa yang berupa soal pemecahan masalah atau penalaran tapi soal tersebut terlalu sukar dan sulit dimengerti oleh peserta didik. Soal yang tersedia juga tidak banyak kuantitas dan juga variasi soalnya. Konteks soal yang digunakan juga bersifat umum, dan memang tidak menekankan adanya perubahan karakter peserta didik setelah membacanya sesuai dengan tujuan pembelajaran matematika yaitu mempunyai sikap menghargai kegunaan matematika dalam kehidupan sehari-hari yaitu memiliki rasa ingin tahu, perhatian, dan minat dalam mempelajari matematika, serta sikap ulet, dan percaya diri dalam pemecahan masalah (Kementerian Pendidikan dan Kebudayaan RI, 2014). Guru juga belum memiliki waktu untuk membuat soal-soal yang bervariasi karena banyaknya tugas yang dilakukan. 5 dari 6 guru juga belum pernah membuat soal dengan konten yang variatif, biasanya guru hanya merubah angka dari soal yang tersedia. 1 dari 6 guru yang mencoba untuk membuat soal dengan mengaitkannya ke candi muara takus merasa bahwa peserta didik sangat antusias karena konten yang diberikan berkaitan dengan objek wisata yang ada di daerahnya.

Wawancara juga dilakukan terhadap 4 orang peserta didik. Dari wawancara diperoleh informasi bahwa siswa tertarik jika diberikan soal-soal yang berkaitan dengan objek wisata, karena mereka senang untuk menungjungi objek wisata dan mendengarkan informasi terkait objek wisata. 
Peserta didik juga diberikan contoh kebudayaan yang ada di Provinsi Riau seperti misalnya kata-kata sapaan di beberapa wilayah. Peserta didik juga merasa sangat antusias karena merasa kata-kata sapaan tersebut unik dan menarik. Seperti contohnya panggilan kakak terhadap kakak laki-laki di wilayah Bangko Kiri, Rokan Hilir disapa dengan sebutan Andak atau Ulung. Sedangkan di wilayah peserta didik itu sendiri panggilan kakak laki-laki hanya di panggil abang, yangmana sama dengan kata sapaan di Bahasa Indonesia. Yang mana hal tersebut berkaitan dengan materi relasi yaitu Relasi Andak dengan kata sapaan abang di daerah Rokan Hilir
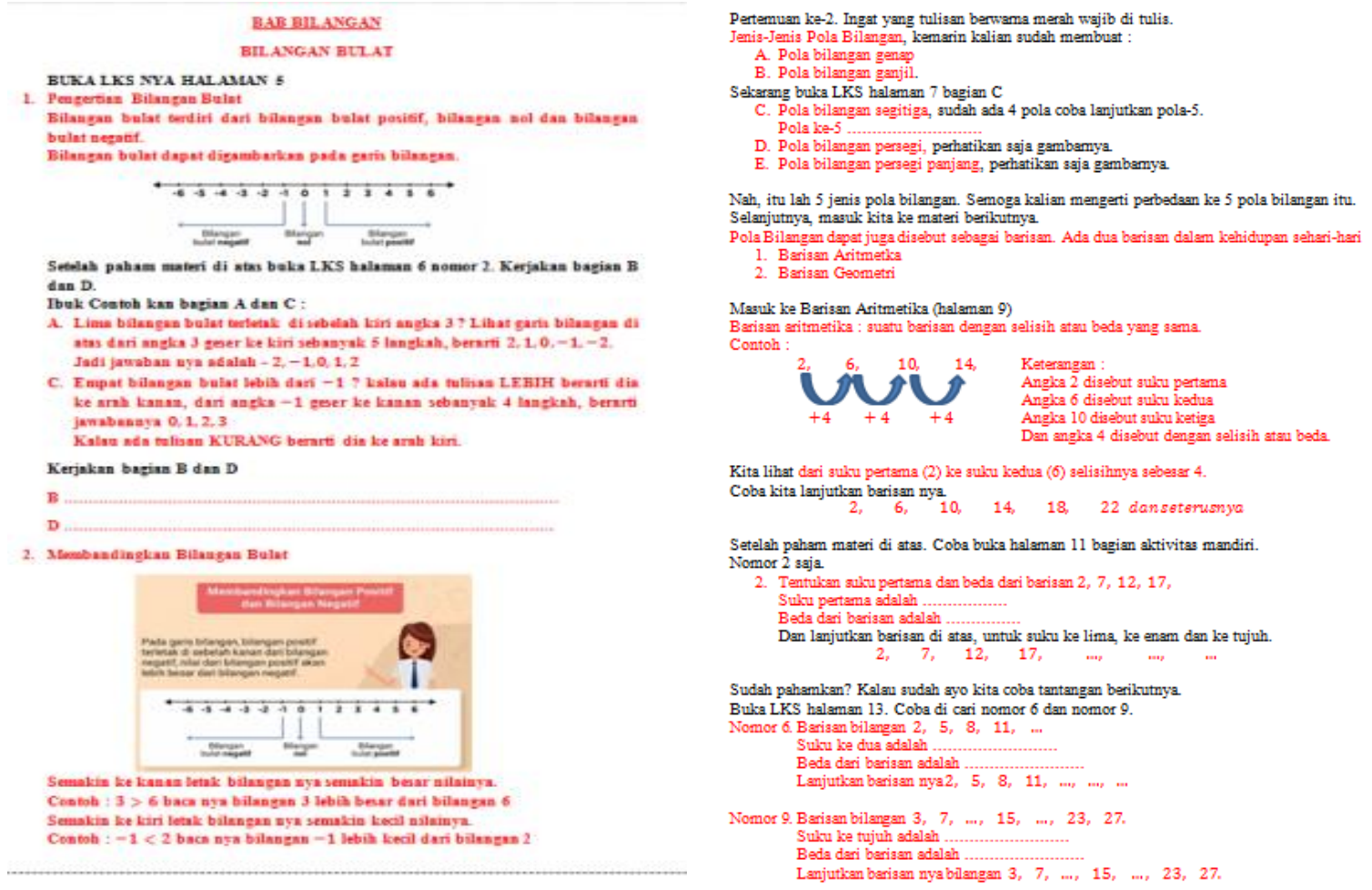

Gambar 4.1 Cuplikan soal yang digunakan pada Materi Kelas VII dan VIII SMP

Berdasarkan wawancara dengan 6 orang guru dan 4 orang peserta didik dari berbagai sekolah diperoleh informasi bahwa diperlukan soal matematika dengan konten kearifan lokal dan daya tarik wisata Riau. Berdasarkan penelitian terdahulu yang dilakukan diperoleh informasi bahwa perlu dilakukan pengembangan soal-soal berbasis kearifan lokal yanmana hal tersebut dapat memberikan efek positif kepada dunia pendidikan. Perlu disediakan buku kumpulan soal matematika berkonteks kearifan lokal suatu daerah yangmana nantinya dapat dijadikan sebagai refrensi dalam penyediaan alat evaluasi pembelajaran matematika(Zulfah, 2018).

\section{Hasil Analisis Karakteristik Peserta Didik}

Analisis karakteristik peserta didik adalah analisis yang dilakukan terhadap usia, proses pemahaman dan pengetahuan pada usia tersebut, karakter peserta didik terkait pandanganya terhadap kebudayaan dan daya tarik wisata Riau. Peserta didik yang dijadikan sebagai objek penelitian adalah peserta didik di kelas VII dan kelas VIII SMP. Usia peserta didik pada kelas VII berada di rentang 12 sampai 13, dan rata-rata berusia 13 tahun. Untuk peserta didik kelas VIII berada di rentang 13 sampai 
Kemampuan Guru Matematika Mempertahankan Substansi Materi Melalui Proses Pembelajaran Online, Febri Giantara, Astuti

14 tahun, dan rata-rata berusia 14 tahun. Pada perkembangannya peserta didik usia SMP berada pada tahap periode perkembangan yang sangat pesat dari segala aspek. Piaget yang menyatakan periode ini dimulai pada usia 12 tahun. Pada usia ini yang berkembang pada peserta didik adalah kemampuan berpikir secara simbolis dan bisa memahami sesuatu secara bermakna, tanpa memerlukan objek yang konkret, bahkan objek yang visual. Peserta didik sudah mampu memahami hal-hal yang bersifat imajinatif(Samiudin, 2017).

Peserta didik juga mulai mengetahui beberapa kebudayaan yang ada di daerahnya. Namun hanya mendengar namanya saja tanpa memahami maksud dan tujuannya. Misalnya adanya istilah bersiacuang di Kabupaten Kampar. Peserta didik pernah mendengar istilah tersebut, namun peserta didik tidak mengetahui apa itu bersiacuang secara pasti dan apa kegunaannya.

\section{Hasil Analisis Kurikulum}

Analisis kurikulum dilakukan pada materi matematika semester ganjil kelas VII dan kelas VIII SMP/Sederajat, pada kurikulum 2013. Berdasarkan analisis kurikulum diperoleh bahwa materi yang dipelajari di kelas VII adalah materi bilangan, himpunan, bentuk aljabar, dan persamaan dan pertidaksamaan linear satu varibel. Pada buku Matematika edisi revisi 2017 kelas VII untuk materi bilangan kompetensi dasar dapat dilihat pada Gambar 1. Untuk kegiatan pembelajaran dapat di lihat pada Gambar 2. Kompetensi dasar materi himpunan dapat dilihat pada Gambar 2. Untuk kegiatan pembelajaran dapat di lihat pada Gambar 2. Kompetensi dasar materi bentuk aljabar dapat dilihat pada Gambar 3. Untuk kegiatan pembelajaran dapat di lihat pada Gambar 2. Kompetensi dasar materi persamaan dan pertidaksamaaan linear satu variabel dapat dilihat pada Gambar 4. Untuk kegiatan pembelajaran dapat di lihat pada Gambar 2. Masing-masing kompetensi dasar tersebut dibuatkan alat evaluasi berupa soal-soal yang dikaitkan dengan kearifan lokal dan daya tarik wisata Riau. Soal-soal yang dihasilkan dikaitkan dengan indikator dari pemahaman konsep.

3.1 Menjelaskan dan menentukan urutan pada bilangan bulat (positif dan negatif) dan pecahan (biasa, campuran, desimal, persen)

3.2 Mlenjelaskan dan melakukan operasi hitung bilangan bulat dan pecahan dengan memanfaatkan berbagai sifat operasi

3.3 Menjelaskan dan menentukan representasi bilangan dalam bentuk bilangan berpangkat bulat positif dan negatif

4.1 Menyelesaikan masalah yang berkaitan dengan urutan beberapa bilangan bulat dan pecahan (biasa, campuran, desimal, persen)

4.2 Menyelesaikan masalah yang berkaitan dengan operasi hitung bilangan bulat dan pecahan

4.3 Menyelesalkan masalah yang berkaitan dengan bilangan dalam bentuk bilangan berpangkat bulat positif dan negatif

Gambar 4.2 Kompetensi Dasar Materi Bilangan 
3.4 Menjelaskan dan menyatakan himpunan, himpunan bagian, himpunan semesta, himpunan kosong, komplemen himpunan menggunakan masalah kontekstual

3.5 Menjelaskan dan melakukan operasi biner pada himpunan menggunakan masalah kontekstual

4.4 Menyelesaikan masalah kontekstual yang berkaitan dengan himpunan, himpunan bagian, himpunan semesta, himpunan kosong, kompelemen himpunan

\subsection{Venyelesaikan masalah kontekstual yang berkaitan dengan operasi biner pada} himpunan

\section{Gambar 4.4. Kompetensi Dasar Materi Himpunan}

3.6. Menjelaskan bentuk aljabar dan unsur-unsurnya menggunakan masalah kontekstual

3.7 Menjelaskan dan melakukan operasi pada bentuk aljabar (penjumlahan, pengurangan, perkalian, dan pembagian)

\subsection{Menyelesaikan masalah yang berkaitan dengan}

\subsection{Menyelesaikan masalah yang berkaitan dengan operasi pada bentuk aljabar}

Gambar 4.6 Kompetensi Dasar Materi Aljabar

\subsection{Menjelaskan persamaan dan pertidaksamaan linear satu variabel dan}

penyelesaiannya

4.8 Menyelesaikan masalah yang berkaitan dengan persamaan dan pertidaksamaan linear satu variabel

Gambar 4.8 Kompetensi Dasar Materi Persamaan dan Pertidaksamaan Linear Satu Variabel

Materi yang dipelajari di kelas VIII Semester 1 yaitu pola bilangan, koordinat kartesius, persamaan garis lurus, sistem persamaan linear dua variabel. Untuk materi pola bilangan kompetensi dasarnya dapat dilihat pada Gambar 1.

3.1 Membuat generalisasi dari pola pada barisan bilangan dan barisan konfigurasi objek

4.1 Menyelesaikan masalah yang berkaitan dengan pola pada barisan bilangan dan barisan konfigurasi objek 
3.2 Menjelaskan kedudukan titik dalam bidang koordinat kartesius yang

dihubungkan dengan masalah kontekstual

4.2 Menyelesaikan masalah yang berkaitan dengan kedudukan titik dalam bidang koordinaat kartesius

3.3 Mendeskripsikan dan menyatakan relasi dan fungsi dengan menggunakan berbagai representasi (kata-kata, tabel, grafik, diagram, dan persamaan)

4.3 Menyelesaikan masalah yang berkaitan dengan relasi dan fungsi dengan menggunakan berbagai representasi

Gambar 4.12 Kompetensi Dasar Koordinat Kartesius

3.3 Mendeskripsikan dan menyatakan relasi dan fungsi dengan menggunakan berbagai representasi (kata-kata, tabel, grafik, diagram, dan persamaan)

4.3 Menyelesaikan masalah yang berkaitan dengan relasi dan fungsi dengan menggunakan berbagai representasi

Gambar 4.14 Kompetensi Dasar Relasi dan Fungsi

3.4 Menganalisis fungsi linear (sebagai persamaan garis lurus) dan menginterprestasikan grafiknya yang dihubungkan dengan masalah kontekstual

4.4 Menyelesaikan masalah kontekstual yang berkaitan dengan fungsi linear sebagai persamaan garis lurus

Gambar 4.16 Kompetensi Dasar Materi Persamaan Garis Lurus

3.5 Menjelaskan sistem persamaan linear dua variabel dan penyelesasiannya yang dihubungkan dengan masalah

4.5 Menyelesaikan masalah yang berkaitan dengan sistem persamaan linear dua variabel

Gambar 4.18 Kompetensi Dasar Materi Sistem Persamaan Linear Dua Variabel

\section{Hasil Analisis Konsep}

Analisis konsep berguna untuk menentukan materi atau isi yang dibutuhkan dalam mengembangkan soal matematika berbasis kearifan lokal dan daya tarik wisata Riau. Materi yang digunakan untuk uji coba penelitian adalah materi himpunan di kelas VII dan materi relasi dan fungsi di kelas VIII. Adapun hasil analisis konsep dari materi pada buku Matematika SMP/MTs Kelas VIII 
Semester 1 keluaran Kementrian Pendidikan dan Kebudayaan Republik Indonesia 2017 Edisi Revisi 2017 adalah sebagai berikut.

\section{Tabel 2.}

Hasil Analisis Konsep di Kelas VII dan VIII SMP/MTs

\begin{tabular}{|c|c|}
\hline Materi di Buku & Perubahan Materi \\
\hline $\begin{array}{l}2.1 \text { Konsep Himpunan } \\
\text { Himpunan dan Bukan Himpunan } \\
\text { Anggota dan Bukan Anggota } \\
\text { Himpunan } \\
\text { 1.1 Penyajian } \\
\text { a. Penyajian himpunan secara } \\
\text { enumerasi } \\
\text { b. Penyajian himpunan dengan } \\
\text { menuliskan sifat yang dimiliki } \\
\quad \text { anggotanya } \\
\text { c. Penyajian Himpunan dengan } \\
\quad \text { notasi pembentuk himpunan } \\
\text { 1.2 Himpunan Kosong dan Himpunan } \\
\quad \text { Semesta } \\
\text { 1.3 Diagram Venn } \\
\text { 2.2 Sifat-sifat Himpunan } \\
\text { 2.1 Kardinalitas Himpunan } \\
\text { 2.2 Himpunan Bagian } \\
\text { 2.3 Himpunan kuasa } \\
\text { 2.4 Kesamaan dua himpunan } \\
\text { 2.3 Operasi Himpunan } \\
\text { 3.1 Irisan } \\
\text { 3.2 Gabungan } \\
\text { 3.3 Komplemen } \\
\text { 3.4 Selisih } \\
\text { 3.5 Sifat-sifat Operasi Himpunan } \\
\text { a. Sifat Idempoten } \\
\text { b. Sifat Identitas } \\
\text { c. Sifat Komutatif } \\
\text { d. Sifat Asosiatif } \\
\text { e. Sifat Distributif }\end{array}$ & $\begin{array}{l}\text { 2.1 Konsep Himpunan } \\
\text { 1.1 Konsep Himpunan } \\
\text { a. Himpunan dan Bukan Himpunan } \\
\text { b. Anggota dan Bukan Anggota } \\
\text { c. Himpunan } \\
\text { 1.2 Penyajian Himpunan } \\
\text { a. Enumerasi } \\
\text { b. Menuliskan sifat yang dimiliki } \\
\text { anggotanya notasi } \\
\text { c. Menyatakan dengan pembentuk himpunan } \\
\text { d. Diagram Venn } \\
\text { 1.3 Jenis-Jenis Himpunan } \\
\text { a. Himpunan Kosong } \\
\text { b. Himpunan Semesta } \\
\text { c. Himpunan Bagian } \\
\text { d. Himpunan Kuasa } \\
\text { e. Dua Himpunan yang Sama } \\
\text { f. Dua Himpunan yang ekuivalen } \\
\text { Sifat-sifat Himpunan } \\
\text { 2.1 Sifat Identitas } \\
\text { 2.2 Sifat Idempoten } \\
\text { 2.3 Sifat Komutatif } \\
\text { 2.4 Sifat Asosiatif } \\
\text { 2.5 Sifat Distributif } \\
\text { Operasi Himpunan } \\
\text { 3.1 Gabungan } \\
\text { 3.2 Irisan } \\
\text { 3.3 Komplemen } \\
\text { 3.4 Selisih }\end{array}$ \\
\hline
\end{tabular}

Hasil analisis konsep untuk materi Relasi dan Fungsi kelas VIII SMP adalah sebagai berikut.

\begin{tabular}{|l|c|}
\hline \multicolumn{1}{|c|}{ Materi di Buku } & \multicolumn{1}{|c|}{ Perubahan Materi } \\
\hline Memahami Relasi & Memahami Relasi \\
3.1 Memahami Bentuk Penyajian Relasi & 3.1 Memahami Bentuk Penyajian Relasi \\
a. Diagram panah & a. Diagram panah \\
b. Diagram Cartesius & b. Diagram Cartesius \\
c. Himpunan Pasangan Berurutan & c. Himpunan Pasangan Berurutan \\
Karakteristik Fungsi & Karakteristik Fungsi \\
3.2 Memahami Ciri-ciri Fungsi & 3.2 Memahami Ciri-ciri Fungsi \\
Bentuk Penyajian Fungsi & Bentuk Penyajian Fungsi \\
3.3 Memahami Bentuk Penyajian Fungsi & 3.3 Memahami Bentuk Penyajian Fungsi \\
a. Himpunan Pasangan Berurutan & a. Himpunan Pasangan Berurutan \\
b. Diagram Panah & b. Diagram Panah \\
c. Dengan Persamaan Fungsi & c. Dengan Persamaan Fungsi \\
\hline
\end{tabular}



d. Dengan Tabel
e. Dengan Grafik

Materi Pengayaan

3. 4 Memahami Korespondensi Satu-satu d. Dengan Tabel

e. Dengan Grafik

Materi Pengayaan

3.4 Memahami Korespondensi Satu-satu

\section{Hasil Analisis Soal yang Tersedia}

Soal-soal matematika yang biasa digunakan oleh guru berasal dari buku paket matematika. Adapaun cuplikan soal yang tersedia adalah sebagai berikut.
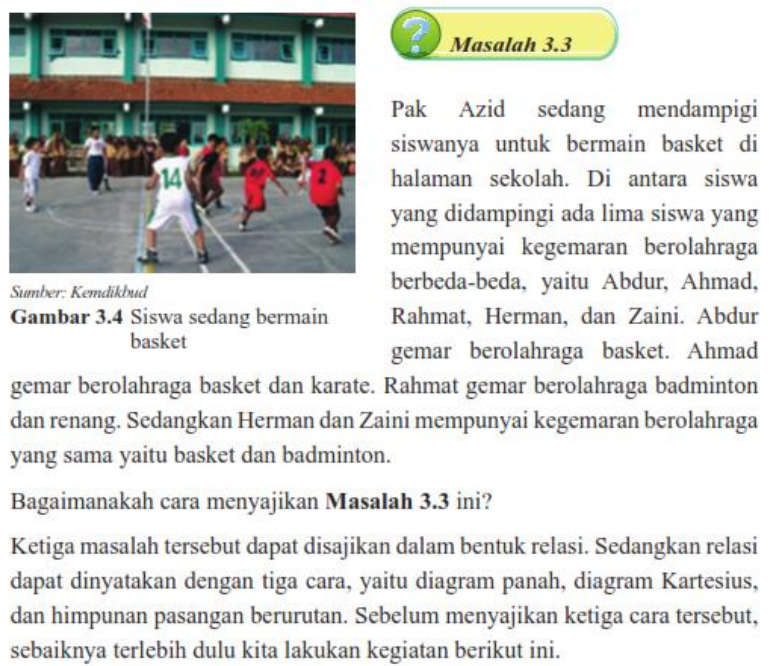

gemar berolahage basket dan kara dan renang. Sedangkan Herman dan Zaini mempunyai kegemaran berolahraga yang sama yaitu basket dan badminton.

Bagaimanakah cara menyajikan Masalah 3.3 ini?

Ketiga masalah tersebut dapat disajikan dalam bentuk relasi. Sedangkan relas dapat dinyatakan dengan tiga cara, yaitu diagram panah, diagram Kartesius, dan himpunan pasangan berurutan. Sebelum menyajikan ketiga cara tersebut, sebaiknya terlebih dulu kita lakukan kegiatan berikut ini.

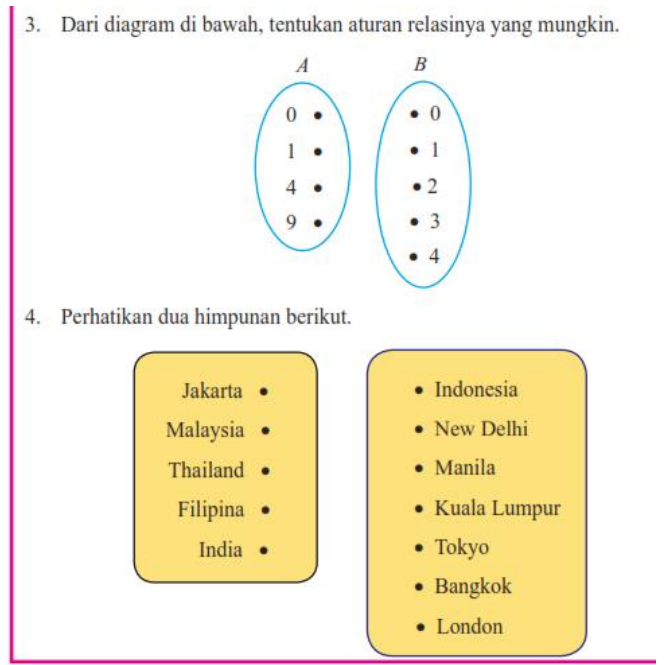

\section{Gambar 1. Cuplikan Soal Materi Konsep Relasi di Kelas VIII SMP/MTs}

Pada Gambar 1 terdapat 3 soal terkait materi konsep relasi. Pada soal tersebut soal-soal yang disajikan sudah dapat mengukur kemampuan pemahaman konsep relasi peserta didik. Soal-soal yang disajikan sifatnya umum yaitu terkait olahraga, bilangan-bilangan, dan Ibu kota Negara. Berikut ini disajikan beberapa bentuk soal lainnya dari materi Relasi dan Fungsi di Kelas VIII SMP?MTs.

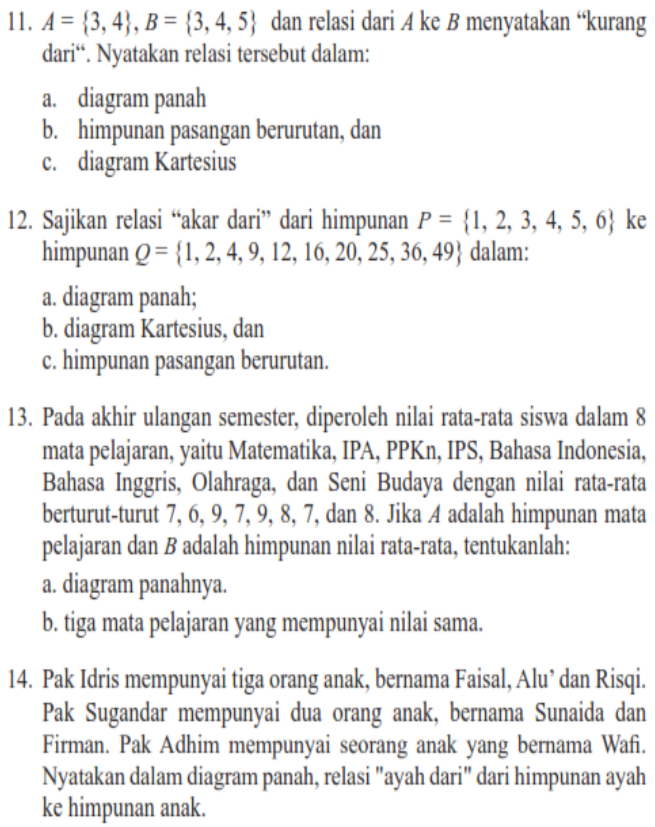

12. Sajikan relasi "akar dari" dari himpunan $P=\{1,2,3,4,5,6\}$ ke himpunan $Q=\{1,2,4,9,12,16,20,25,36,49\}$ dalam:

a. diagram panah;

b. diagram Kartesius, dan

c. himpunan pasangan berurutan.

13. Pada akhir ulangan semester, diperoleh nilai rata-rata siswa dalam 8 mata pelajaran, yaitu Matematika, IPA, PPKn, IPS, Bahasa Indonesia, Bahasa Inggris, Olahraga, dan Seni Budaya dengan nilai rata-rata berturut-turut 7, 6, 9, 7,9, 8, 7, dan 8 . Jika $A$ adalah himpunan mata pelajaran dan $B$ adalah himpunan nilai rata-rata, tentukanlah: a. diagram panahnya.

b. tiga mata pelajaran yang mempunyai nilai sama.

14. Pak Idris mempunyai tiga orang anak, bernama Faisal, Alu' dan Risqi. Pak Sugandar mempunyai dua orang anak, bernama Sunaida dan Firman. Pak Adhim mempunyai seorang anak yang bernama Wafi. Nyatakan dalam diagram panah, relasi "ayah dari" dari himpunan ayah ke himpunan anak.

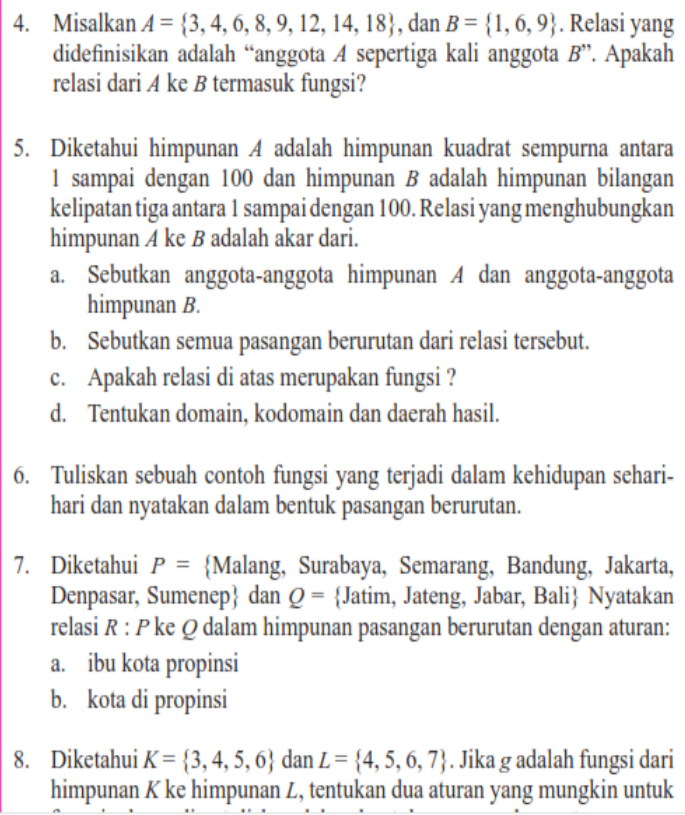

4. Misalkan $A=\{3,4,6,8,9,12,14,18\}$, dan $B=\{1,6,9\}$. Relasi yan didefinisikan adalah "anggota $A$ sepertiga kali anggota $B$ ". Apakah relasi dari $A$ ke $B$ termasuk fungsi?

5. Diketahui himpunan $A$ adalah himpunan kuadrat sempurna antara 1 sampai dengan 100 dan himpunan $B$ adalah himpunan bilangan kelipatan tiga antara 1 sampai dengan 100. Relasi yang menghubungkan himpunan $A$ ke $B$ adalah akar dari.

a. Sebutkan anggota-anggota himpunan $A$ dan anggota-anggota himpunan $B$.

b. Sebutkan semua pasangan berurutan dari relasi tersebut.

c. Apakah relasi di atas merupakan fungsi ?

d. Tentukan domain, kodomain dan daerah hasil.

6. Tuliskan sebuah contoh fungsi yang terjadi dalam kehidupan seharihari dan nyatakan dalam bentuk pasangan berurutan.

7. Diketahui $P=$ Malang, Surabaya, Semarang, Bandung, Jakarta, Denpasar, Sumenep $\}$ dan $Q=\{$ Jatim, Jateng, Jabar, Bali $\}$ Nyatakan relasi $R: P$ ke $Q$ dalam himpunan pasangan berurutan dengan aturan:

a. ibu kota propinsi

b. kota di propinsi

8. Diketahui $K=\{3,4,5,6\}$ dan $L=\{4,5,6,7\}$. Jika $g$ adalah fungsi dari himpunan $K$ ke himpunan $L$, tentukan dua aturan yang mungkin untuk

Gambar 2. Cuplikan Soal Pada Materi Relasi dan Fungsi di Kelas VIII SMP/MTs. 
Berdasarkan cuplikan soal pada materi relasi dan fungsi di kelas VIII SMP?MTs pada Gambar 2. Juga diperoleh data bahwa konteks yang digunakan bersifat umum.

\section{Studi Literature}

Berdasarkan studi literature terdapat banyak penelitian terkait pengembangan soal-soal matematika dengan konteks kebudayaan. Terdapat artikel dengan judul pengembangan soal matematika model PISA Level 4, 5, 6 menggunakan konteks Lampung. Berdasarkan penelitian tersebut diperoleh informasi bahwa soal-soal matematika yang menggunakan konteks mempermudah peserta didik dalam memahami dan mensituasikan matematika kedalam konteks sehingga membantu peserta didik dalam menggunakan kemampuan literasinya dalam menjawab soal, dan dapat menantang pola berpikir matematis peserta didik(Yudi Yunika Putra, Zulkardi, 2016). Selanjutnya pada artikel dengan judul pengembangan instrument kecakapan matematis dalam konteks kearifan lokal Budaya Banten pada materi bangun ruang sisi datar. Berdasarkan hasil penelitian dan pembahasan diperoleh informasi bahwa soal kecakapan matematis berbasis kearifan lokal budaya Banten yang dikembangkan memiliki efek potensial yang baik terhadap hasil tes peserta didik, ditandai dengan hasil tes kecakapan matematis peserta didik termasuk dalam kategori baik(Khaerunnisa \& Pamungkas, 2018).

\section{KESIMPULAN}

Berdasarkan hasil Preliminary research maka diperlukan melaksanakan pengembangan soal matematika berbasis kearifan lokal dan daya tarik wisata Riau. Hal ini sesuai dengan kebutuhan akan adanya variasi soal-soal yang dapat dijadikan sebagai referensi melaksanakan latihan, ulangan harian, ulangan tengah semester, ataupun ujian akhir semester. Ditinjau dari karakteristik peserta didik yang memang tertarik dengan konteks kearfian lokal dan daya tarik wisata Riau karena domisili peserta didik yang memang di Provinsi Riau. Berdasarkan analisis kurikulum diperoleh bahwa seluruh KD dapat disajikan dalam konteks kearifan lokal dan daya tarik wisata Riau. Perlunya dilakukan perbaikan pada materi himpunan di kelas VII SMP?MTs agar tercapainya tujuan pembelajaran matematika yang diinginkan. Berdasarkan studi literature memang terdapat efek positif dalam menyajikan soal-soal dengan konteks budaya ataupun kearifan lokal ditandai dengan hasil tes kecakapan matematis peserta didik dengan kategori baik.

\section{DAFTAR PUSTAKA}

Adelina Yuristia. (2018). Pendidikan Sebagai Transformasi Kebudayaan. https://doi.org/10.1017/CBO9781107415324.004

Dewi, Y. K. (2015). Pendidikan Karakter dalam Pembelajaran Matematika. Math Didactic: Jurnal Pendidikan Matematika, 1(2), 124-131. https://doi.org/10.33654/math.v1i2.13

Hariyanto. (2016). Mengembangkan Karakter Siswa Berbasis Kearifan Lokal dan Kemampuan Akademik melalui Implementasi Metode Penemuan Terbimbing (Guided Discovery). Pros. 
Kemampuan Guru Matematika Mempertahankan Substansi Materi Melalui Proses Pembelajaran Online, Febri Giantara, Astuti

Semnas Pend. IPA Pascasarjana UM, 771-780.

Kementerian Pendidikan dan Kebudayaan RI. (2014). Peraturan Mendikbud Nomor 58 tahun 2014 tentang Kurikulum 2013 Sekolah Menengah Pertama (SMP) / Madrasah Tsanawiyah (MTs).

Khaerunnisa, E., \& Pamungkas, A. S. (2018). Pengembangan Instrumen Kecakapan Matematis Dalam Konteks Kearifan Lokal Budaya Banten Pada Materi Bangun Ruang Sisi Datar. Kreano, Jurnal Matematika Kreatif-Inovatif, 9(1), 17-27. https://doi.org/10.15294/kreano.v9i1.11210

Musfah, J. (2012). Pendidikan Holistik: Pendekatan Lintas Perspektif. In Prenada Media. Prenada Media.

Nasional, K. P. (2010). Bahan Pelatihan Penguatan Metodologi Pembelajaran Berdasarkan Nilainilai Budaya untuk Membentuk Daya Saing dan Karakter Bangsa. Jakarta: Kementerian Pendidikan Nasional Badan Penelitian dan Pengembangan Pusat Kurikulum.

Parwati, N. N., \& Ganesha, U. P. (2014). EFEKTIVITAS PENGINTEGRASIAN NILAI KEARIFAN LOKAL BALI DALAM MODEL PEMBELAJARAN PEMECAHAN.

Pratama, O. R., Lutfianto, M., \& Noviartati, K. (2019). Pengembangan Soal Matematika Mirip TIMSS Yang Memuat Nilai Karakter. Kreano, Jurnal Matematika Kreatif-Inovatif, 10(2), 179185. https://doi.org/10.15294/kreano.v10i2.17970

Rakhmawati, I. A., \& Alifia, N. N. (2018). Kearifan Lokal dalam Pembelajaran Matematika sebagai Penguat Karakter Siswa. Jurnal Elektronik Pembelajaran Matematika, 5(2), 193.

Samiudin. (2017). Pentingnya Memahami Perkembangan Anak Untuk. Pancawahana, 12(1), 1-9.

Sumaryanta. (2013). Pengembangan Soft Skill dalam Pembelajaran Matematika. Jakarta.

Supiyati, S., Hanum, F., \& Jailani. (2019). Ethnomathematics in sasaknese architecture. Journal on Mathematics Education, 10(1), 47-57. https://doi.org/10.22342/jme.10.1.5383.47-58

Tilaar. (2002). Pendidikan, Kebudayaan, dan Masyarakat Madani. In Remaja Rosdakarya. Bandung: Remaja Rosdakarya.

Yudi Yunika Putra, Zulkardi, Y. H. (2016). Pengembangan Soal Matematika Model PISA Level 4, 5 , 6 menggunakan Konteks Lampung. Kreano: Jurnal Matematika Kreatif-Inovatif, 7(1), 10-16.

Zulfah, Z. (2017). TAHAP PRELIMINARY RESEARCH PENGEMBANGAN LKPD BERBASIS PBL UNTUK MATERI MATEMATIKA SEMESTER 1 KELAS VIII SMP. Jurnal Cendekia: Jurnal Pendidikan Matematika, 1(2), 1-12. Retrieved from http://journal.stkiptam.ac.id/index.php/cendekia/article/view/184

Zulfah, Z. (2018). ANALISIS KEBUTUHAN PENGEMBANGAN SOAL BERBASIS. 2(1), 1-6. 